\title{
Coastal Planning Strategies for Adaptation to Sea Level Rise: A Case Study of Mokpo, Korea
}

\author{
Yumi Lee \\ Department of Landscape Architecture, Graduate School of Environmental Studies, Seoul National University, \\ Seoul, South Korea \\ Email:yumil@snu.ac.kr
}

Received 13 February 2014; revised 14 March 2014; accepted 21 March 2014

Copyright @ 2014 by author and Scientific Research Publishing Inc.

This work is licensed under the Creative Commons Attribution International License (CC BY).

http://creativecommons.org/licenses/by/4.0/

(c) (i) Open Access

\begin{abstract}
Climate change and sea level rise necessitate adaptation strategies for coastal areas. This paper showcases five strategies for sea level rise adaptation: hard protection, soft protection, accommodation, retreat, and attack. This study proposes adaptation measures and a phased development strategy for coastal areas of Mokpo, an old port city on the southwestern tip of the Korean Peninsula that has been expanded by land reclamation. Mokpo presently experiences frequent flooding during high-water and storm events; due to their low elevation and land subsidence, most of the reclaimed areas are susceptible to future inundation via sea level rise. The fundamental adaptation strategies for the impact areas are: hard protection of important infrastructures via multi-tiered terraces; the retreat of coastal developments accompanied by green buffer zones such as wetlands and parks to accommodate temporary inundation; and up-leveling the ground for new development and phased relocation of existing development. Through the case study of Mokpo, the paper emphasizes the importance of resilient planning strategies for urban development, and highlights both the challenges and opportunities for sea level rise adaptation.
\end{abstract}

\section{Keywords}

Sea Level Rise; Adaptation Strategies; Coastal Cities; Waterfront Development

\section{Introduction}

Coastal cities are presently facing unprecedented challenges associated with climate change. It has been estimated that population densities in coastal regions are about three times higher than the global average [1], and the issue of sea level rise is one of the most critical impacts on the future of coastal cities worldwide [2] [3]. The sustainability of coastal cities is threatened by frequent flood events, increasing wave heights, reduction of tidal 
flats and wetlands, and damage to shoreline infrastructure [4] [5]. Multiple studies have reported that integrated assessment methods and the implementation of adaptation strategies are urgently required in consideration of coastal cities worldwide in order to ensure their viability [6] [7].

Korea is surrounded by water on three sides, and has therefore actively utilized coastal areas for dwelling, recreation, commerce, generating power, etc. Coastal development continues at present, and several mega-scale reclamation projects are in progress. The impacts of climate change and sea level rise in the coastal areas in Korea are evident [8]; however, it is difficult to account for sea level rise in development plans. One of the main reasons is the uncertainty of future estimates [9]. Researchers have proposed multiple scenarios and assumptions for sea level rise [10]-[12], and it is difficult to evaluate the probability of each scenario. Many studies focus on assessing the impacts of sea level rise, but few have proposed potential strategic responses that are applicable for adaptation. Therefore, the objectives of this study are: 1) to categorize sea level rise adaptation strategies in consideration of site advantages; 2) to identify coastal areas that might be affected by future sea level rise; and 3) to assign planning strategies for sea level rise adaptation based on site condition and intended uses. In order to communicate the results, this study developed a set of diagrams visualizing the phases of adaptation.

Responding to climate change often means developing remedies for natural disasters such as temporary floods or storms. It is difficult to prepare strategies for changes that might occur in the distant future. This uncertainty requires diverse adaptation strategies rather than a single solution. There is growing awareness of such issues among practitioners, as evidenced by speculative designs for San Francisco Bay [13], and in multiple planning strategies-retreat, defense, and attack - for one city, which facilitate visual comparison of the city's future under differing response scenarios [14]. One example of implementing adaptations to sea level rise is HafenCity in Hamburg, Germany. HafenCity is located on the Elbe River, where flood prevention became a priority of urban planning and architectural design. All buildings and roads are designed to be built 8 meters above sea level, since the river level rises by more than three meters twice a day [15]. Open spaces become connectors between the water and buildings by providing parks, paths, and plazas that are designed to accommodate temporary inundation.

Among the variety of sea level rise scenarios, the present study uses a sea level rise inundation map plotted by the Korea Environment Institute (KEI) in 2012. According to the inundation map, sea levels in coastal areas of Korea will increase by $1.36 \mathrm{~m}$ by 2100 . The inundation maps are based on the Representative Concentration Pathways (RCP) 8.5 scenario, reflecting a 100-year storm surge. Land use maps were generated by the Korean Ministry of Environment in 2007 and updated in 2009. Topographical maps are in ITRF 2000 based on the ASTER DEM.

\section{Sea Level Rise Adaptation}

Previous researches identified that adaptation to sea level rise in coastal areas generally follows three strategies: protection, accommodation, and retreat [16] [17]. Subsequent studies have shown attack as another strategic response to sea level rise [14]. Table 1 shows sections and axonometric diagrams of four adaptation strategies, including representative systems and site advantages.

The protection strategy divides into two types. Hard protection such as dikes or levees is the most common coastal defense strategy. It proposes hard structures to block the inflow of sea water, and protects facilities and critical infrastructure that would be difficult to move or relocate. It is advantageous to plan for protection of the maximum land area with the minimum required infrastructure. Soft protection involves the use of natural sedimentation and vegetation to form a buffer zone. It is relatively low-cost and eco-friendly, and can be provided by natural processes that can be accelerated through minimal human effort, such as wetland restoration or planning waterfront parks. This strategy is particularly advantageous where there are nearby sand dunes and forests. New coastal wetlands act like sponges, reducing water flow during flood events.

The accommodation strategy reduces the impact of sea level rise through changes in human behavior or infrastructure while maintaining existing uses of coastal areas. For example, it might involve modifying existing infrastructure for adaptive land uses, raising the ground level or improving drainage facilities, encouraging saltresistant crops, restoring sand beaches, and improving flood warning systems.

The retreat strategy mitigates the risk of sea level rise by relocating developments further from the coastline. It discourages development in high-risk coastal areas and encourages development at low-risk inland areas that are usually at higher elevation. Such adaptation can be time-consuming and expensive, because development of the 
Table 1. Sea level rise adaptation strategies.

\begin{tabular}{|c|c|c|c|c|}
\hline Strategies & Features & Methods & Site Advantages & Diagrams \\
\hline Hard & $\begin{array}{l}\text { Dikes } \\
\text { Levees } \\
\text { Sea Walls } \\
\text { Groins }\end{array}$ & $\begin{array}{l}\text { Build physical } \\
\text { barriers to block } \\
\text { water }\end{array}$ & $\begin{array}{l}\text { For hard-to-move } \\
\text { facilities and } \\
\text { infrastructure on flat } \\
\text { ground }\end{array}$ & \\
\hline Soft & $\begin{array}{l}\text { Mangroves } \\
\text { Wetlands } \\
\text { Sand dunes } \\
\text { Tidal Flats }\end{array}$ & $\begin{array}{l}\text { Create buffer with } \\
\text { vegetation or } \\
\text { landforms }\end{array}$ & $\begin{array}{l}\text { For maintaining } \\
\text { shoreline at sites } \\
\text { with existing coastal } \\
\text { forest or sand dunes }\end{array}$ & \\
\hline Accommodation & $\begin{array}{l}\text { Raising level } \\
\text { Desalination } \\
\text { Drainage } \\
\text { Alarm system }\end{array}$ & $\begin{array}{l}\text { Upgrade functions } \\
\text { while maintaining } \\
\text { location }\end{array}$ & $\begin{array}{l}\text { For redevelopment } \\
\text { projects or facilities at } \\
\text { sites without high } \\
\text { ground nearby }\end{array}$ & \\
\hline Retreat & $\begin{array}{c}\text { Relocation } \\
\text { Abandonment }\end{array}$ & $\begin{array}{l}\text { Relocate facilities to } \\
\text { low-risk uplands }\end{array}$ & $\begin{array}{l}\text { For residential and } \\
\text { public facilities at sites } \\
\text { with low-risk } \\
\text { uplands nearby }\end{array}$ & \\
\hline Attack & $\begin{array}{c}\text { Land Reclamation } \\
\text { Piers } \\
\text { Ports } \\
\text { Harbors }\end{array}$ & $\begin{array}{l}\text { Extend facilities } \\
\text { towards water }\end{array}$ & $\begin{array}{l}\text { For facilities requiring } \\
\text { direct access to water }\end{array}$ & \\
\hline
\end{tabular}

a. Re-organized after [14] [16] [17].

new site must be accompanied by a relocation policy. However, if planned proactively, it can be the most sustainable and effective adaptation to the uncertainty of future sea level rise.

The attack strategy advances the coastline seaward, building out onto the water with piers, decks, or land reclamation. Many coastal cities developed their waterfront by an attack strategy that is particularly important for facilities and infrastructure requiring direct access to the sea, such as airports and harbors. However, it leaves parts of the city still vulnerable to flooding, and might not provide sustainable long-term benefit [14].

\section{Development Strategies: Mokpo}

The study site is Mokpo, a port city in southwest Korea that comprises tidal flats and low hills. Mokpo has been expanded through a century of land reclamation, starting from the Japanese colonial period. As shown in Figure 1, about $60 \%$ of the total land area is reclaimed [18]. Figure 2 indicates that $40 \%$ of the entire city is predicted to be inundated in 2100 due to sea level rise. The inundation map shows that most of the reclaimed areas are susceptible to future inundation by sea level rise. Land reclamation is on-going, and Mokpo currently experiences frequent flooding during high-water and storm events.

This study focuses on the analysis of flood maps, reclamation progress, future inundation areas, land uses, topography, and potential development plans to derive planning strategies that permit Mokpo to adapt to sea level rise. The city was divided into northwestern and southern regions, and various analyses were conducted to identify regions prone to flooding. We selected three areas, as shown in Figure 3, in which either a development project is in the planning phase or the potential for development is high. Specific sites are selected in consideration of their development potential and the existence of current development plans. This research suggests multiple planning and design strategies for adaptation suitable for each of these target regions: multi-tiered terraces for flood protection; sloped coastal buffer with vegetation; and phased relocation of urban cores. 


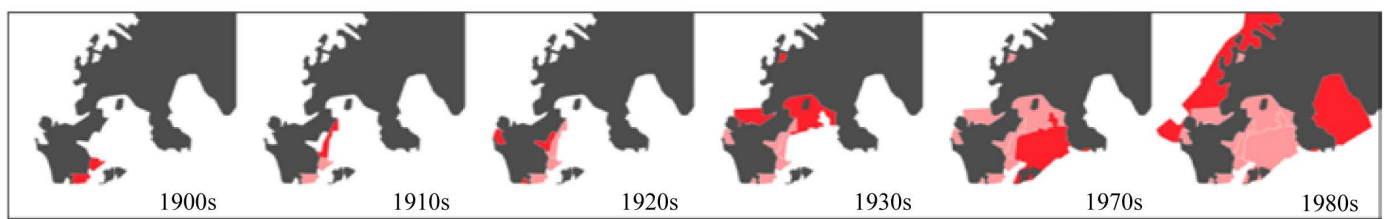

Figure 1. Land reclamation in Mokpo, 1900-1980. Re-organized after [18].

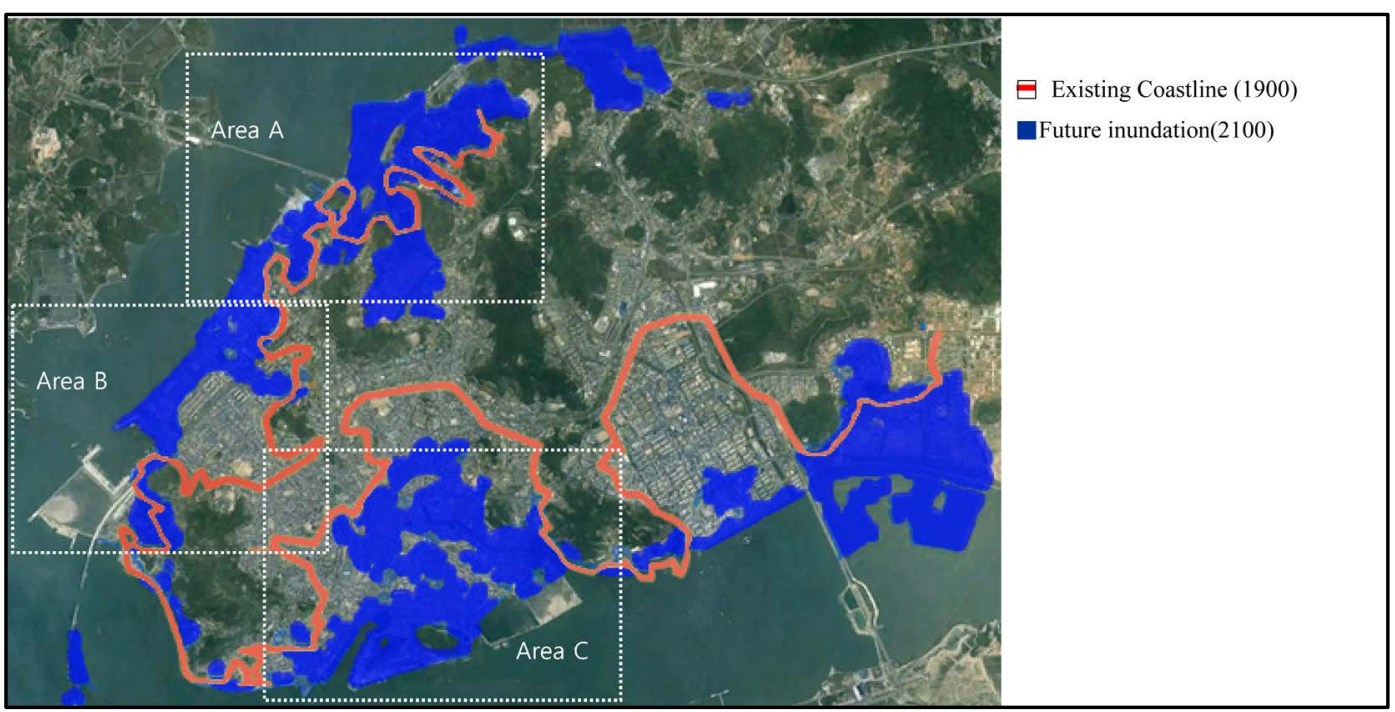

Figure 2. Previous coastline (1900) and future inundation map (2100) of Mokpo.

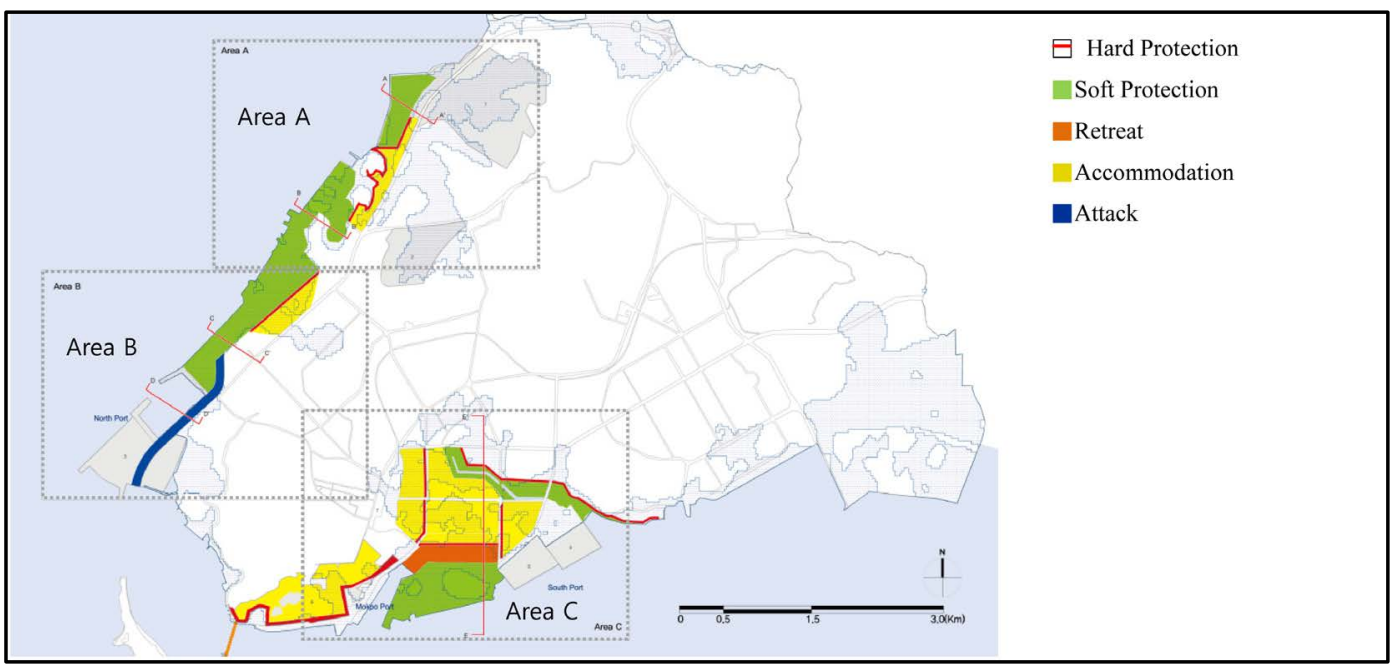

Figure 3. Coastal planning strategy plan for Mokpo.

\subsection{Multi-Tiered Terraces: Area A}

In Area A shown in Figure 3, undeveloped areas, coastal swamps, and industrial areas co-occur and cannot be demarcated, and an industrial complex is planned for construction in 2017. This area was reclaimed from the sea; the current landscape, with traces of coastal swamps and saline fields inhabited by migratory birds, was formed by reclamation beginning in the 1980s as shown in Figure 1. The flood prediction map reveals that both the coastal swamps and sites planned for future development are in flood-prone areas.

For Area A, we propose adaptive measures involving hard protection as shown in Section A-A' of Figure 4; these measures will help ensure flood protection by filling in the lowlands between two hills. In the area in 
which the industrial complex is planned, multi-tiered terraces are proposed to allow the coastal area to act as a buffer in the event of high water. The multi-tiered terraces would serve two purposes: as flood-prevention structures, and to provide a buffer area to be used for open space and roads when the sea level rises. The dredged soils will be used for the back-slope and site preparation, forming a soft protection zone that will function as a water-filled area during high tide and as a coastal marsh during low tide.

\subsection{Vegetated Buffers: Area B}

Area B shown in Figure 3 is another reclaimed area developed in the 1980s; currently, it accommodates public facilities such as maritime police stations and seafood markets. An offshore area approximately $20 \mathrm{~m}$ wide remains vacant. The area around the North Port is a dense commercial space, and large-scale reclamation is underway to build an oceanic leisure complex that is scheduled for completion in 2019. The agroindustrial complex, where a reinforced drainage system is under construction, is frequently flooded. According to the flood prediction map, flooding occurs along the prior coastal line, and the majority of the planned development areas are within this zone.

Because Area B has no breakwater facilities, we recommend that the target area first be transformed to a backland capable of accommodating the planned use, followed by dredging of the coastal area to generate fill material as shown in Section B-B' of Figure 4. The land created by the dredged material should have a gradual gradient down to the shoreline, acting as a soft protection zone by introducing suitable vegetation. The area formed by the fill would have the dual function of preventing flooding and accommodating an urban waterfront.

\subsection{Phased Relocation of Urban Cores: Area C}

Area $\mathrm{C}$ is a long-standing reclamation area, the majority of which is a frequently-inundated lowland. In Figure 3 , the area south of the new city center comprises low-density residential areas of 1 - 2-story houses and high-density residential areas with mid-rise apartment buildings. The port area, currently accommodating Mokpo Port and the Ferry Terminal, was formed by reclamation beginning in the 1900s, and was redeveloped in 2003. The three islands that formerly made up the site have now been incorporated within the reclaimed area and redeveloped as a tourist zone. A marine science center has recently been completed and construction of a museum is planned in this area. Analysis of the flood prediction map reveals that all of the currently planned facilities lie within a flood-prone zone, which extends from the seashore to approximately $3 \mathrm{~km}$ back into the residential areas.

The protection measures suggested for Area $\mathrm{C}$ are based on the accommodation approach, in which gradual displacement of under-utilized blocks and new residential development is proposed in order to protect the existing urban functions. The functions of the underdeveloped areas can be moved to lower-risk residential backland at a higher elevation. At the same time, extension of the port area is planned in order to encourage port activities in the coastal area, and there are plans for a commercial zone connecting Mokpo's railway station and port, in addition to a high-density residential quarter.

The phasing proposed for Area C (see Figure 5) is as follows: In phase 1, Samhak-dong and Dongmyeong-dong,

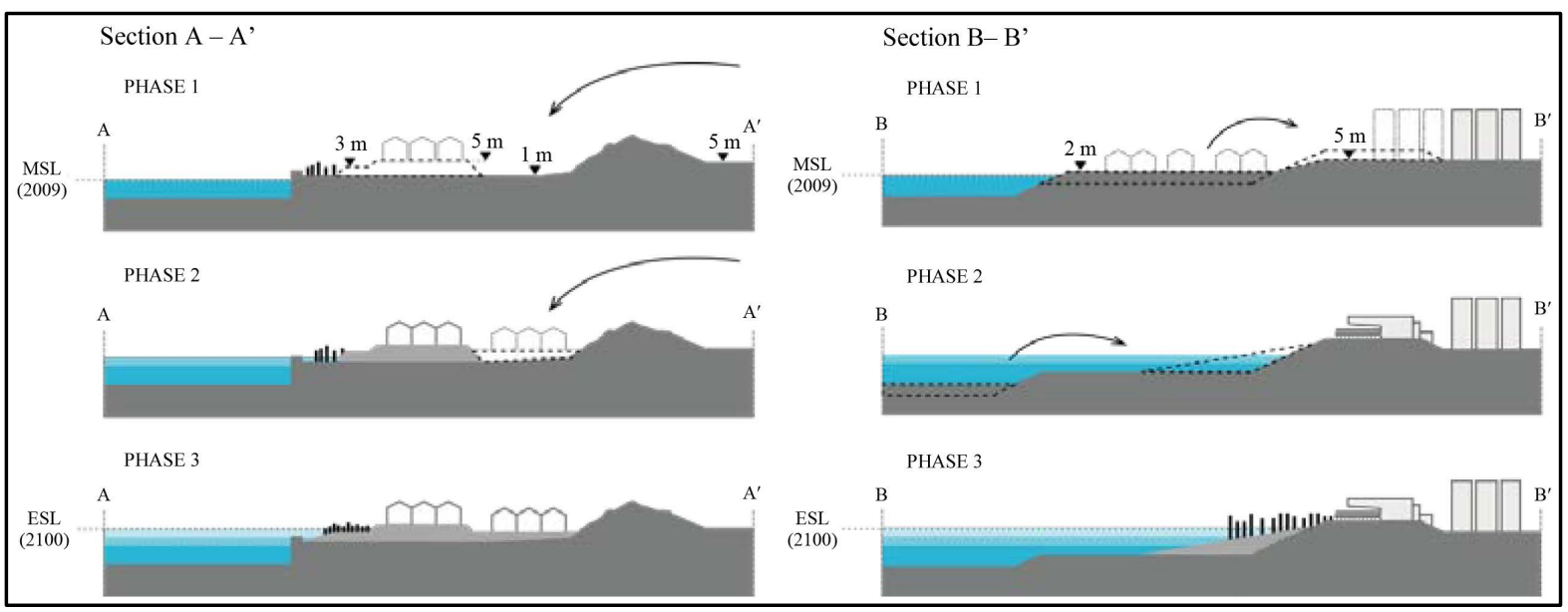

Figure 4. Coastal development phasing for Areas A and B. 


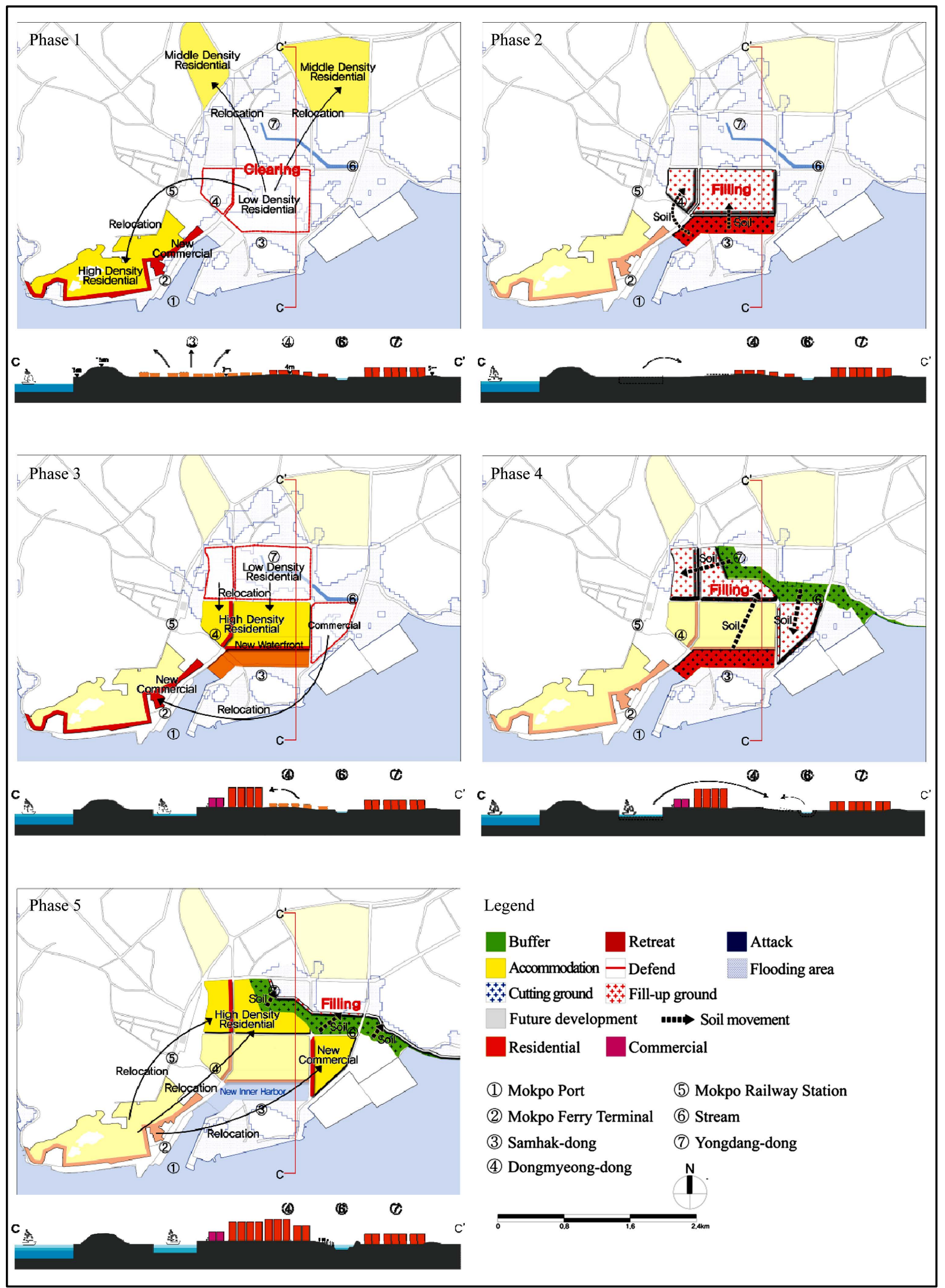

Figure 5. Coastal development phasing for Area C. 
where flooding and sea level rise will have significant impact, will be vacated and residents will move to lowrisk hinterland or nearby residential development areas. In phase 2, the cut soils from the Mokpo port extension area will be used as fill for the areas in Samhak-dong and Dongmyeong-dong, and a new inner port will be developed with public facilities. In phase 3, high-density housing will be built on the filled areas of Samhak-dong and Dongmyeong-dong, and the commercial area will be shifted to the port front or the coastal area. In phase 4, the cross-section of the river channel will be increased by cutting back both sides, and the soil will be used for building riverbanks and filling Yongdang-dong. Finally, in phase 5, a vegetated area will be created on the slope of the riverbank, and Yongdang-dong will accommodate new urban development. As a result, high-risk areas will be accommodated by up-leveling low ground, and a new inner port and public facilities will be developed on the newly-built waterfront.

\section{Conclusions and Discussion}

This study proposes adaptation measures and suggests potential developments for coastal areas of Mokpo, one of the major coastal cities in Korea that is particularly vulnerable to flooding in the event of sea level rise. In Mokpo, the adaptation strategies applied for three areas are: 1) preventing flood by building earth mounds; 2) creating sloped buffer zones by vegetation distribution; 3) relocating facilities to the hinterland and securing a flood-safe elevation.

In conclusion, the research analyzes physical and functional as well as environmental characteristics of three areas of Mokpo that were selected for design adaptations. The fundamental adaptation strategies include selective protection of major infrastructure and multi-tiered terraces for flood protection; designing wetlands and parks to accommodate temporary inundation and thereby function as vegetated buffers for coastal areas; and phased relocation of urban development in combination with raising the ground level. In addition, the research shows that reclaimed land is more susceptible to future inundation, due to its low elevation and ground subsidence.

In future research, adaptation strategies will consider the more powerful tidal waves that are predicted to result from sea-level rise and climate change. Further feasibility studies of the proposals will require field analysis of the site topography through accurate measurement of ground elevation. The feasibility of each adaptation strategies needs to be compared, based on the scale of the site, land use, natural environment factors, phasing strategy, and economic assessments.

Both planners and designers need to reflect these strategies in the city planning and urban design of coastal cities. This research attempts to offer insight into approaches for adapting to sea level rise and, in the process, to highlight both the challenges and opportunities. It is of utmost importance to consider the impact of sea level rise for present and future coastal development. To contribute to practical sea-level rise adaptation plans, one of the ultimate goals of this research is to initiate a regulatory policy within the urban planning process for the sustainable development of coastal areas.

\section{Acknowledgements}

The findings of this research were initially presented in the report, National Assessment on Sea Level Rise Impact of Korean Coast in the Socioeconomic Context II, compiled by the Korea Environmental Institute in 2012. The author is grateful to the Korea Environment Institute for funding this research, and particularly Dr. Kwangwoo Cho, for providing related data including the inundation map. Graphic production and data collection for this research were supported by Suyoung Choi, Bonwoo Koo, Heewon Lee, Seul Lee, Juyeon Park, Haeseung Sung, and Hyunjun Yim. The author thanks all participants for their assistance.

\section{References}

[1] Small, C. and Nicholls, R.J. (2003) A Global Analysis of Human Settlement in Coastal Zones. Journal of Coastal Research, 19, 584-599. http://www.jstor.org/stable/4299200

[2] Fuchs, R.J. (2010) Cities at Risk: Asia’s Coastal Cities in an Age of Climate Change. Asia Pacific Issues, 96, 1-12.

[3] Dasgupta, S. (2007) The Impact of Sea Level Rises on Developing Countries: A Comparative Analysis. World Bank Policy Research Working Paper, 4136, 1-51.

[4] Nicholls, R.J. (1999) Increasing Flood Risk and Wetland Losses Due to Global Sea-Level Rise: Regional and Global 
Analyses. Global Environmental Change, 9, 69-87. http://dx.doi.org/10.1016/S0959-3780(99)00019-9

[5] Nicholls, R.J. (2004) Coastal Flooding and Wetland Loss in the 21st Century: Changes under the SRES Climate and Socio-Economic Scenarios. Global Environmental Change, 14, 69-86. http://dx.doi.org/10.1016/j.gloenvcha.2003.10.007

[6] Hallegatte, S., et al. (2011) Assessing Climate Change Impacts, Sea Level Rise and Storm Surge Risk in Port Cities: A Case Study on Copenhagen. Climatic Change, 104, 113-137. http://dx.doi.org/10.1007/s10584-010-9978-3

[7] Cooper, J.A. and Lemckert, C. (2012) Extreme Sea-Level Rise and Adaptation Options for Coastal Resort Cities: A Qualitative Assessment from the Gold Coast, Australia. Ocean \& Coastal Management, 64, 1-14. http://dx.doi.org/10.1016/j.ocecoaman.2012.04.001

[8] Cho, K., et al. (2012) National Assessment on Sea Level Rise Impact of Korean Coast in the Socio-economic Context II. Report 2012-19. Korea Environment Institute, Seoul.

[9] Hallegatte, S. (2009) Strategies to Adapt to an Uncertain Climate Change. Global Environmental Change, 19, $240-247$. http://dx.doi.org/10.1016/j.gloenvcha.2008.12.003

[10] Storch, H. and Downes, N.K. (2011) A Scenario-Based Approach to Assess Ho Chi Minh City’s Urban Development Strategies Against the Impact of Climate Change. Cities, 28, 517-526. http://dx.doi.org/10.1016/j.cities.2011.07.002

[11] Dawson, R.J., Hall, J.W., Bates, P.D. and Nicholls, R.J. (2005) Quantified Analysis of the Probability of Flooding in the Thames Estuary under Imaginable Worst-Case Sea Level Rise Scenarios. International Journal of Water Resources Development, 21, 577-591. http://dx.doi.org/10.1080/07900620500258380

[12] Rahmstorf, S. (2007) A Semi-Empirical Approach to Projecting Future Sea-Level Rise, Science, 315, 368-370. http://dx.doi.org/10.1126/science.1135456

[13] The Rising Tides International Competition for Ideas Responding to Sea Level Rise in San Francisco Bay and Beyond. http://www.risingtidescompetition.com

[14] Building Futures and ICE (2010) Facing Up to Rising Sea-Levels: Retreat? Defend? Attack? Report. London.

[15] Stark, A. (Ed.) (2013) Hafen City Hamburg: Essentials Quarters Projects. Hafen City Hamburg GmbH. Hamburg.

[16] IPCC CZMS (1990) Strategies for Adaptation to Sea Level Rise. Report. IPCC CZMS, Hague.

[17] Nicholls, R.J. (2011) Planning for the Impacts of Sea Level Rise. Oceanography, 24, 144-157. http://dx.doi.org/10.5670/oceanog.2011.34

[18] Kim, J. (2009) A Study on the Formation and Characteristics of Urban Structure of Mokpo. Ph.D. Thesis, Chonnam National University, Gwangju. 